CLINICAL HEMORHEOLOGY, Vol. 10, page 347, 1990

$0271-5198 / 90 \$ 3.00+.00$ Printed in the USA.

Copyright (c) 1990 Pergamon Press plc. All rights reserved.

\title{
CONTENTS OF BIORHEOLOGY, VOLUME 27, NUMBER 1
}

VOLUME 27, NUMBER 1

\section{Contents}

A.L. Copley and A. Silberberg

A.L. Copley

J.M. Norton

M. Boynard and J.C. Lelievre

K. Arai, M. Iino, H. Shio and N. Uyesaka

H.S. Kage, H. Engelhardt and E. Sackmann
1 Editorial

Opening Address

3 Fluid Mechanics and Biorheology

Papers

21 The effect of macrocytosis on rat erythrocyte deformability during recovery from phenylhydrazine-induced anemia

39 Size determination of red blood cell aggregates induced by dextran using ultrasound backscattering phenomenon

47 Further investigations of red cell deformability with nickel mesh

67 A precision method to measure average viscoelastic parameters of erythrocyte populations

79 Abstracts: International Symposium on Biofluid Mechanics and Biorheology, Munich, FRG, 25-28 June 1989

103 Abstracts: Symposium on Biorheology, Montreal, Canada, 25 October 1989

109 Letters to the Editors-in-Chief

121 Announcements

123 Contents of CLINICAL HEMORHEOLOGY, Volume 9, Number 5

I Software Survey Section 